NOTA CIENTÍFICA

Karyotypes of Akodon orophilus Osgood 1913 and Thomasomys sp. (Rodentia: Sigmodontinae) from Huánuco, Peru

\title{
Cariotipos de Akodon orophilus Osgood 1913 y Thomasomys sp. (Rodentia: Sigmodontinae) de Huánuco, Perú
}

\author{
Víctor Pacheco ${ }^{1}$, Jesús H. Córdova ${ }^{2}$ and Margarita Velásquez ${ }^{3}$
}

\begin{abstract}
1 Departamento de Mastozoología Museo de Historia Natural, Universidad Nacional Mayor de San Marcos, Av. Arenales 1256, Jesús María, Lima, Perú.

Email: vpachecot@gmail.com

2 Departamento de Herpetología, Laboratorio de Citogenética Molecular "Javier Zapata Arias", Museo de Historia Natural, Universidad Nacional Mayor de San Marcos.

3 Laboratorio de Genética HumanaFacultad de Ciencias Biologicas, Universidad Nacional Mayor de San Marcos.
\end{abstract}

\begin{abstract}
Conventional chromosomal preparations were made of three native mice from Huánuco, Peru: a male and a female of Thomasomys sp., and a male of Akodon orophilus. Thomasomys sp. had a karyotype of $2 n=42, X Y$ $(n=21)$, meanwhile $A$. orophilus presented $2 n=22, X Y(n=11)$. Comparisons between chromosomal pairs from the existent literature indicate that both are new karyotypes. Thomasomys sp. has a distinct sexual $Y$ chromosome, the only metacentric $(\mathbf{m})$ reported for the genus. The chromosomes $\mathrm{X}$ and $\mathrm{Y}$ of $A$. orophilus are acrocentrics (a); and the length of chromosome $\mathrm{Y}(2 / 3$ of the length of $\mathrm{X})$ distinguishes $A$. orophilus from other congeneric. Because the structural differences between the sexual chromosomes usually generates mechanism of reproductive isolation at intraspecific level and are bigger still in interspecific crosses, we concluded that the karyotypes reported here support the validity of the species $A$. orophilus and suggest that Thomasomys sp. represents a new species to science.
\end{abstract}

Keywords: Akodon, Thomasomys, karyotype, Yungas, Sigmodontinae

\section{Resumen}

Se procesaron preparados cromosómicos convencionales de tres ratones procedentes de Huánuco, Perú: una hembra y un macho de Thomasomys sp., y otro macho de Akodon orophilus. Thomasomys sp. presentó un cariotipo $2 n=42, X Y(n=21)$, en tanto que $A$. orophilus presentó $2 n=22, X Y(n=11)$. Thomasomys sp. tiene un cromosoma sexual $Y$ distinguible, por ser el único metacéntrico $(\mathbf{m})$ entre los reportados para el género. A. orophilus tiene los cromosomas $X$ e $Y$ acrocéntricos (a), alcanzando el $Y$ los $2 / 3$ de la longitud del $X$, característica que la diferencia de otras especies congenéres. Dada la importancia que tienen las diferencias estructurales entre los cromosomas sexuales como usual mecanismo generador de problemas reproductivos a nivel intraespecífico, y mayores aún en cruzas interespecíficas, consideramos que los cariotipos reportados aquí apoyan la validez de la especie $A$. orophilus y sugiere que Thomasomys sp. representa una especie nueva para la ciencia.

Palabras clave: Akodon, Thomasomys, cariotipos, Yungas, Sigmodontinae.

\section{Introduction}

Peru is considered one of the twelve more biomegadiverse countries of the world (Lamas 1982, McNeely et al. 1990); and it ranks fifth in regard to mammalian diversity in the world (Pacheco et al. 2009). Some 162 species of rodents are currently reported for Peru and the report of several new species is known to be in preparation (Pacheco et al. 2009). This scenario compels us to devote time and resources to better know our diversity.

At present, the study of the karyotypes is an excellent approach to solve problems of identification, species determination, classification, phylogeny and distribution of the species, and a fundamental parameter - and sometimes irreplaceable - for this purpose. Thus, this method has been widely used in the systematics of Neotropical rodents (Reig and Useche 1976, Gardner and Patton 1976, Reig et al. 1980, Aguilera et al. 2000).

Akodon and Thomasomys comprise two of the most specious genus of Sigmodontinae with 41 and 36 species respectively (Musser and Carleton 2005). In Peru, Akodon is represented by 14 species and Thomasomys by 18 species (Pacheco et al. 2009). A summary of karyotype information for Akodon from Peru was reported by Patton and Smith (1992). Adequate karyotype information for Thomasomys from Peru is found in Gardner and Patton (1976) and Salazar-Bravo and Yates (2007), but a summary is still missing. Karyotype information for several species of Akodon and Thomasomys are still missing.
This study reports for the first time the karyotype of Akodon orophilus, an endemic rodent to Peru, and Thomasomys sp., an apparently new species to science (Patton and Smith 1992, Pacheco 2003), based on three samples obtained from the cloud forests of Palmapampa, of Huánuco, Peru.

\section{Material and methods}

Two karyotypes were evaluated based on conventional chromosome staining (somatic and germinal cells) from three rodents collected in the field and prepared in the laboratory: a male and female of Thomasomys sp. (MUSM 17826 and 17827 respectively), and a male of Akodon orophilus (MUSM 17795). These specimens were obtained during an mammals diversity survey from Palmapampa, ( approximately at $20 \mathrm{~km} \mathrm{SE}$ of Chaglla), along the road from Chaglla to Tomayrica, Distrito Chaglla, Provincia Pachitea, Departamento Huánuco, at 3020 m elevation, $09^{\circ} 53^{\prime} 12^{\prime \prime} \mathrm{S}, 7^{\circ} 53^{\prime} 22^{\prime \prime} \mathrm{W}$, from 15 to 26 of May 2000. The habitat is a typical montane forests or Yungas, and moderately fragmented by potato agriculture. This locality was described and a map presented by Lehr et al. (2002).

The species were identified based on external and craneodental characteristics by the first author (VP) following Patton and Smith (1992) for Akodon, and Pacheco (2003) for Thomasomys. The specimens are deposited in the Museo de Historia Natural, Universidad de San Marcos (MUSM). Chromosomal preparations and staining follow the protocols described by 
Córdova (1993) adapted to rodents. Pictures were taken with two photomicroscopes (Leitz Orthoplan-Orthomat and LeitzOrthoplan 20) with film Agfa Ortho-25, and printed in bromide Kodak paper, degree 2 and 4 . In all samples the karyotypes were obtained by counting the chromosomes of at least seven of the better metaphases (and diakinesis in males) for individual, by arranging and qualifying the chromosomes according to Levan et al. (1964) and Green and Sessions (1991). In this work, "acrocentrics" (a) is used here for mammalian chromosomes and comprise the "subtelocentrics" and "telocentrics" chromosomes of the Green \& Sessions's chromosomal nomenclature.

\section{Results and discussion}

These results represent the first karyotypes for Akodon orophilus and Thomasomys sp. These are here described, illustrated and compared with relevant works in the literature.

\section{Akodon orophilus}

The specimen of $A$. orophilus (MUSM 17795) has a karyotype of $2 \mathrm{n}=22, \mathrm{FN}=40$ (Fig. 1, 4; Table 1). All the autosomes are biarmed ( 8 metacentric, $\mathbf{m}$; and 2 submetacentric pairs, $\mathbf{s m}$ ), meanwhile the $\mathrm{X}$ and $\mathrm{Y}$ are acrocentrics $(\mathbf{a})$. The $\mathrm{Y}$ chromosome is relatively long because in size it is $2 / 3$ the length of the $\mathrm{X}$ chromosome. Gardner and Patton (1976) reported a karyotype of $2 \mathrm{n}=22, \mathrm{FN}=40$ for Akodon sp. (Ancash, Peru), but X and $\mathrm{Y}$ are $\mathbf{s m}$ in this taxon and $\mathbf{a}$ in our sample. Likewise, Patton

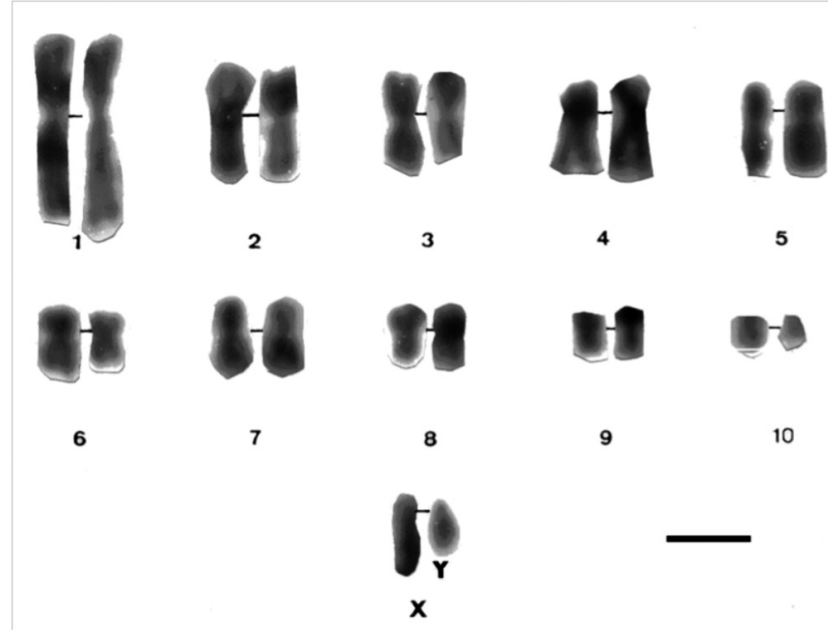

Figure 1. Karyotype of Akodon orophilus from Palmapampa, Departament of Huánuco, Peru (MUSM 17795) (scale bar $=5 \mu \mathrm{m}$ ).

Table 1. Karyometric data of Akodon orophilus.

\begin{tabular}{cccc}
\hline $\begin{array}{c}\text { Cromosomal } \\
\text { Pair }\end{array}$ & $\begin{array}{c}\text { Relative } \\
\text { Length }\end{array}$ & $\begin{array}{c}\text { Centromeric } \\
\text { Index }\end{array}$ & $\begin{array}{c}\text { Chromosomal } \\
\text { Type }\end{array}$ \\
\hline 1 & 21.024 & 0.447 & $\mathrm{~m}$ \\
2 & 12.191 & 0.407 & $\mathrm{~m}$ \\
3 & 9.541 & 0.432 & $\mathrm{~m}$ \\
4 & 9.452 & 0.306 & $\mathrm{sm}$ \\
5 & 8.657 & 0.316 & $\mathrm{sm}$ \\
6 & 6.36 & 0.423 & $\mathrm{~m}$ \\
7 & 6.184 & 0.429 & $\mathrm{~m}$ \\
8 & 6.007 & 0.482 & $\mathrm{~m}$ \\
9 & 3.799 & 0.444 & $\mathrm{~m}$ \\
10 & 2.65 & 0.333 & $\mathrm{sm}$ \\
$\mathrm{X}$ & 8.834 & 0.201 & $\mathrm{a}$ \\
$\mathrm{Y}$ & 5.3 & 0.167 & $\mathrm{a}$ \\
\hline
\end{tabular}

(1987) and Patton et al. (1990) reported a similar karyotype $(2 \mathrm{n}=22)$ for $A$. aerosus and $A$. torques, from Cuzco Department; but these have a submetacentric X. In addition, $A$. torques has a subtelocentric $\mathrm{Y}$ which is $1 / 2$ the length of the $\mathrm{X}$ chromosome.

According to the revision by Patton and Smith (1992) the genus Akodon in Peru presents chromosomal complements from $2 \mathrm{n}=22$ to $2 \mathrm{n}=40$, as is seen in Akodon juninensis $(2 \mathrm{n}=40)$, A. lutescens $(2 \mathrm{n}=40), A$. boliviensis $(2 \mathrm{n}=40), A$. mollis $(2 \mathrm{n}=$ 22 to 36-38), $A$. subfuscus $(2 \mathrm{n}=40), A$. torques $(2 \mathrm{n}=22-26), A$. aerosus $(2 \mathrm{n}=22-40), A$. albiventer $(2 \mathrm{n}=40)$, and $A$. kofordi $(2 \mathrm{n}$ = 40). The karyotype of $A$. orophilus and the diploid number of Peruvian populations of $A$. fumeus were unknown at that time. All these karyotypes are markedly different to the one reported here for A. orophilus. Hsu and Benirschke (1973) reported a karyotype of $A$. orophilus with $2 \mathrm{n}=26$ from specimens from Department of Ayacucho, but these were later identified as $A$. torques by Patton and Smith (1992).

Structural differences of sexual chromosomes reinforce the separation of Akodon orophilus from other congeners, although the species is considered a complex group and might represent more than one species (Patton and Smith 1992, Smith and Patton 2007).

\section{Thomasomys sp.}

The specimens of Thomasomys sp. have a karyotype of $2 \mathrm{n}$ $=42, \mathrm{n}=21, \mathrm{FN}=47$ (Fig. 2, 4; Table 2). All autosomes are acrocentrics except the pairs 1, 5 and 20 that are metacentrics (m). In regard to the sexual pair, the chromosome $\mathrm{X}$ is $\mathbf{a}$, and the $\mathrm{Y}$ is $\mathbf{~ m}$. Secondary constrictions were found in the medial region of long arm of $\mathrm{X}$ sexual pair and the distal region of the long arm of autosomal pair 10 (Fig. 3A, B).

The species of the genus Thomasomys are a uniform group characterized by a diploid number of 42 or 44 , and a predominantly acrocentric autosomic complement (Gardner and Patton 1976). Numerically our results are similar to those of Thomasomys monochromos from Colombia (Gardner and Patton

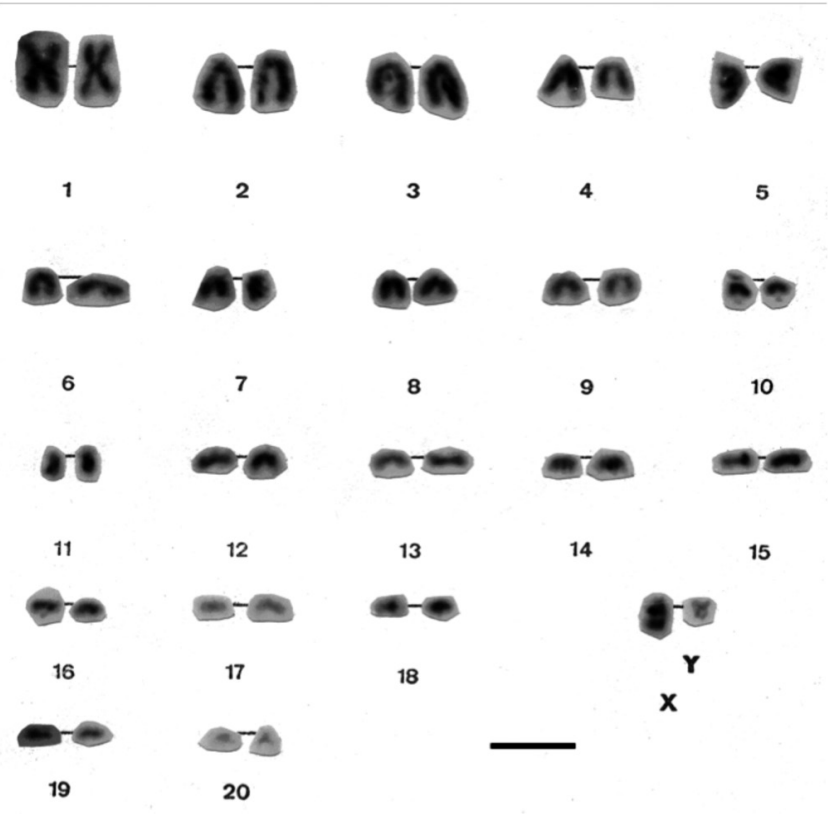

Figure 2. Karyotype of Thomasomys sp. from Palmapampa, Huánuco, Peru (MUSM 17826). Scale bar $=5 \mu \mathrm{m}$. 


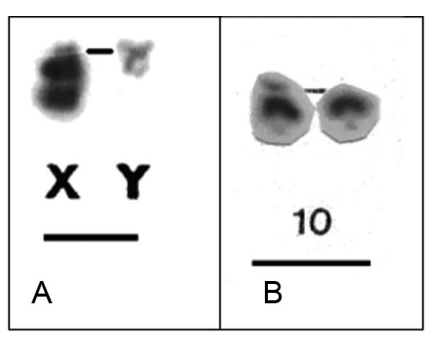

Figure 3. Amplification of chromosomes of Thomasomys sp. A.- Observe the metacentric $Y$ chromosome and the secondary constriction in the long arm of $X$ in the sexual pair. B.- The pair 10 has secondary constrictions in the long arm.

Table 2. Karyometric data of Thomasomys sp.

\begin{tabular}{cccc}
\hline $\begin{array}{c}\text { Cromosomal } \\
\text { Pair }\end{array}$ & $\begin{array}{c}\text { Relative } \\
\text { Length }\end{array}$ & $\begin{array}{c}\text { Centromeric } \\
\text { Index }\end{array}$ & $\begin{array}{c}\text { Chromosomal } \\
\text { Type }\end{array}$ \\
\hline 1 & 12.52 & 0.475 & $\mathrm{~m}$ \\
2 & 9.984 & 0.083 & $\mathrm{a}$ \\
3 & 8.558 & 0.124 & $\mathrm{a}$ \\
4 & 8.24 & 0.101 & $\mathrm{a}$ \\
5 & 8.082 & 0.481 & $\mathrm{~m}$ \\
6 & 5.864 & 0.111 & $\mathrm{a}$ \\
7 & 4.596 & 0.12 & $\mathrm{a}$ \\
8 & 4.12 & 0.108 & $\mathrm{a}$ \\
9 & 3.962 & 0.094 & $\mathrm{a}$ \\
10 & 3.803 & 0.122 & $\mathrm{a}$ \\
11 & 3.645 & 0.121 & $\mathrm{a}$ \\
12 & 3.487 & 0.081 & $\mathrm{a}$ \\
13 & 3.328 & 0.037 & $\mathrm{a}$ \\
14 & 2.853 & 0.055 & $\mathrm{a}$ \\
15 & 2.357 & 0.074 & $\mathrm{a}$ \\
16 & 1.426 & 0.104 & $\mathrm{a}$ \\
17 & 1.109 & 0.093 & $\mathrm{a}$ \\
18 & 0.951 & 0.086 & $\mathrm{a}$ \\
19 & 0.792 & 0.072 & $\mathrm{a}$ \\
20 & 0.634 & 0.451 & $\mathrm{~m}$ \\
$\mathrm{X}$ & 6.339 & 0.04 & $\mathrm{a}$ \\
$\mathrm{Y}$ & 3.17 & 0.443 & $\mathrm{~m}$ \\
\hline
\end{tabular}

Table 3. Summary of karyotypes reported for species of Thomasomys.

\begin{tabular}{|c|c|c|c|c|c|}
\hline T. niveipes & 24 & 42 & M or SM & A & Gómez-Laverde et al. 1997 \\
\hline T. laniger & 40 & 40 & $\mathrm{M}$ or $\mathrm{SM}$ & A & Gómez-Laverde et al. 1997 \\
\hline T. emeritus ${ }^{1}$ & 42 & 40 & M & A & Aguilera et al. 2000 \\
\hline T. monochromos & 42 & 42 & SM & A & Gardner and Patton 1976 \\
\hline T. aureus & 44 & 42 & A & A & Gardner and Patton 1976 \\
\hline T. paramorum & 44 & 42 & A & A & Haynie et al. 2006 \\
\hline T. vestitus & 44 & 42 & A & A & Aguilera et al. 2000 \\
\hline T. andersoni & 44 & 42 & $?$ & $?$ & Salazar Bravo and Yates 2007 \\
\hline T. kalinowskii & 44 & 44 & A & A & Gardner and Patton 1976 \\
\hline T. notatus & 44 & 44 & A & A & Gardner and Patton 1976 \\
\hline
\end{tabular}


for Thomasomys; however, it differs from other karyotypes by the biarmed Y chromosome and biarmed autosomal pairs 1, 5 and 20 , and $2 n=42$ instead of $2 n=44$. Karyotype data then reinforce the suggestion based on morphology that Thomasomys sp. is a new species (Pacheco 2003).

\section{Acknowledgments}

We thank to Lily Arias, Marina Villalobos, Claudia Chung, Angela Vásquez, and César Aguilar for their assistance during the field work. To Carlos Tello for helping in the curatorial work of these samples, and to Dan Vivas for his comments on karyotype morphology.

\section{Literature cited}

Aguilera M., A. Pérez-Zapata, J. Ochoa \& P. Soriano. 2000. Karyology of Aepeomys and Thomasomys (Rodentia: Muridae) from the Venezuelan Andes. Journal of Mammalogy 81(1): $52-28$

Córdova J.H. 1993. Estudios cariotípicos y problemas taxonómicos en el grupo de Bufo spinulosus (Amphibia: Anura). Tesis, Título Profesional de Biólogo, mención en Genética. Facultad de Ciencias Biológicas. Universidad Nacional Mayor de San Marcos.

Gardner A.L. \& J.L. Patton. 1976. Karyotypic variation in oryzomyine rodents (Cricetinae) with comments on chromosomal evolution in the Neotropical cricetine complex. Occasional Papers of the Museum of Zoology, Louisiana State University 49: 1-48.

Gómez-Laverde M., O. Montenegro-Díaz, H. López-Arévalo, A. Cadena \& M.L. Bueno. 1997. Karyology, morphology, and ecology of Thomasomys laniger and $\mathrm{T}$. niveipes in Colombia. Journal of Mammalogy 78: 1282-1289.

Green D.M. \& S.K. Sessions. 1991. Nomenclature for chromosomes. In: D.M. Green \& S.K. Sessions, eds. Amphibian Cytogenetics and Evolution. Academic Press, New York. Pp. 431- 432.

Haynie M.L., J.G. Brant, L.R. McAliley, J.P. Carrera, M.A. Revelez, D.A. Parish, X. Viteri, C. Jones \& C.J. Phillips. 2006. Investigations in a Natural Corridor Between Two National Parks in Central Ecuador: Results from the Sowell Expedition, 2001. Occasional Papers Museum of Texas Tech University 263: 1-16.

Hsu T.C. \& K. Benirschke. 1973. Atlas of Mammalian Chromosomes 7: folio 314

Lamas G. 1982. A preliminary zoogeographical division of Peru based on butterfly distributions (Lepidoptera: Papilionoidea). In: G.T. Prance, ed. Biological diversification in the Tropics. Columbia University Press, New York. Pp. 336-357.

Lehr E., C. Aguilar \& G. Köhler. 2002. Two sympatric new species of Phrynopus (Anura: Leptodactylidae) from a cloud forest in the Peruvian Andes. Journal of Herpetology, 36(2):
208-216.

Levan A., K. Fredga \& A.A. Sandberg. 1964. Nomenclature for centromeric positions on chromosomes. Hereditas, 52: 201-220.

McNeely J., K. Miller, W. Reid, R. Mittermeier \& T. Werner. 1990 Conserving the world's biological diversity. - UICN, Gland, Switzerland, WRI, CI, WWF-US, and the World Bank; Washington.

Musser G.G. \& M.D. Carleton. 2005. Superfamily Muroidea. In: D.E. Wilson and D.M. Reeder, eds. Mammal Species of the World, Third Edition. Johns Hopkins University Press, Baltimore, MD. Vol 2: 894-1531.

Pacheco V. 2003. Phylogenetic analyses of the Thomasomyini (Muroidea: Sigmodontinae) based on morphological data. $\mathrm{Ph}$ D. dissertation. The City University New York, New York, USA.

Pacheco V., R. Cadenillas, E. Salas, C. Tello \& H. Zeballos. 2009. Diversidad y endemismo de los mamíferos del Perú. Revista Peruana de Biología 16(1): 5-32.

Patton J.L. 1987. Patrones de distribución y especiación de fauna de mamíferos de los bosques nublados andinos del Perú. Anales Museo de Historia Natural Valparaíso 17: 87-94.

Patton J.L. \& M.F. Smith. 1992. Evolution and systematics of the akodontine rodents (Muridae:Sigmodontinae) of Peru, with emphasis on the genus Akodon. Memorias del Museo de Historia Natural, Universidad Nacional Mayor de San Marcos, 21:83-104.

Patton J.L., P. Myers \& M.F. Smith. 1990. Vicariant versus gradient models of diversification: the small mammal fauna of eastern Andean slopes of Peru. In: G. Peters and R. Hutterer, eds. Vertebrates in the Tropics. Zoologisches Forschunginstitut und Museum Alexander Koenig, Bonn. Pp. 355-371.

Reig O.A. \& M. Useche. 1976. Diversidad cariotípica y sistemática en poblaciones venezolanas de Proechimys (Rodentia: Echimydae), con datos adicionales sobre poblaciones de Perú y Colombia. Acta Cientifica Venezolana 27: 132-140.

Reig O.A., M. Aguilera, M.A. Barros \& M. Useche. 1980. Chromosomal speciation in a Rassenkreis of venezuelan spiny rats (Genus Proechimys, Rodentia, Echimydae). Genetica 52/53: 291-312.

Salazar-Bravo J. \& T.L. Yates. 2007. A new species of Thomasomys (Cricetidae: Sigmodontinae) from central Bolivia. In: D.A. Kelt, E.P. Lessa, J. Salazar-Bravo, and J.L. Patton, Eds. The quintessential naturalist: honoring the life and legacy of Oliver P. Pearson. University of California Publications in Zoology. Pp. 747-774.

Smith M.F. \& J.L. Patton. 2007. Molecular phylogenetics and diversification of South American grass mice, genus Akodon. In: D.A. Kelt, E.P. Lessa, J. Salazar-Bravo, and J. L. Patton, Eds. The quintessential naturalist: honoring the life and legacy of Oliver P. Pearson. University of California Publications in Zoology 134. Pp. 827-858. 